\title{
統合ファサードにおける斜行配置ルーバーによる室内光環境 LIGHTING ENVIRONMENT OF DIAGONALLY ARRANGED LOUVER ON INTEGRATED FAÇADE SYSTEM
}

\author{
彦根＼cjkstart茂*1, 三澤 温*2, 中村 慎*3, 岩本靜男*4, 岩田 衛*5 \\ Shigeru HIKONE, Yutaka MISAWA, Makoto NAKAMURA, \\ Shizuo IWAMOTO and Mamoru IWATA
}

\begin{abstract}
Building façades have a critical role in creating urban landscape, can be effectively used to reduce energy and its impact on the environment and incorporate structural seismic resisting elements in the perimeter zone. To satisfy these requirements the authors propose an integrated façade concept to incorporate architectural, façade and environmental design requirements. In Europe remarkable façade engineering development has taken place over the last two decades resulting in elegant facades and a reduction in environmental impact but needs development in Japan to take account of the different environmental climates. To satisfy these requirements this paper proposes the use of a diagonally arranged louver system. In many cases louvers are not installed because of the restricted view and darkness created in the building interior. To overcome these problems a full scale diagonal louver mock up was created to evaluate illumination levels and the quality of the internal environment and external appearance. The mock up was used to measure illumination levels and correlated with results form a lighting analysis tool.
\end{abstract}

Keywords: Refurbishment, Facade, Louvre, Daylight factor, Full scale mock-up test, Day light analysis 既存改修，ファサード，ルーバー，昼光率，実物大実験，光環境解析

\section{1. 序論}

大都市における建築ストックを新陳代謝していくには、従来のス クラップ・アンド・ビルド一辺倒ではなく、建物を改修しながら性 能を向上させる方法が重要である。環境負荷低減や建物の継続的使 用の観点からも改修時に性能を向上させていく方法が今後さらに重 要となる。なかでも建物の外周部を構成するファサードは都市景観 を形成する重要な要素であるとともに、建物内部を外的環境から保 護し、室内環境に直接的な影響を与える要素である。そのため、既 存建物の改修において、ファサードを適切に再構築することは、建 物外観を一新すると共に環境負荷低減などの性能向上が期待できる。

一方で、既存建物には最新の耐震基準を満足しない既存不適格建 築物が多く存在し、大地震時の被害を低減するために耐震改修を行 う必要がある。耐震要素の配置には建物外周部が適しているため外 部に露出して補強材が設置されることが多い。しかし、これらの補 強材はファサードと無関係に設計されることが多く、景観は劣悪と なり環境性能や建築ストックの向上とも相反する現状となっている。

\section{2. 目的}

筆者らは、このような現況を踏まえ、既往の研究1) 5) において、 既存建築物に耐震補強を行う場合について、諸性能（主に、景観・ 安全・環境）を向上させる統合ファサードシステムの評価軸設定、 分析及び実物件一の適用を行ってきた。また、既報6)においては、こ れらのシステムのうち、耐震補強材の部材寸法を極小にした斜行配 置した座屈拘束ブレース（以下、BRBと寸る）を用いた耐震改修シス テムの構造性能を確認した。BRBは部材寸法を最小断面にした補強材 のため、ファサード構成材との調和が期待できる。そのためBRBは、 構造要素に加え、ルーバーなどの環境装置と成り得る発展性がある。 本研究は、BRBを環境装置兼用の構造要素と位置づけ、構造及び環 境性能を統合させた斜行配置したルーバー（以下、斜行ルーバーと する）を提案する。また、斜行ルーバーの実物大モックアップを用 いた室内照度測定及び解析による室内光環境の検証を行い、斜行ル ーバーの設計への適用を図るものである。

\footnotetext{
*1 オーヴ・アラップ・アンド・パートナーズ . ジャパン・リミテッド日本における代表者

*2 オーヴ・アラップ・アンド・パートナーズ . ジャパン・リミテッド ファサードエンジニア

*3 神奈川大学大学院工学研究科建築学専攻 大学院生

*4 神奈川大学工学部建築学科 准教授. 工博

* 5 神奈川大学工学部建築学科 教授·工博
}

Ove Arup \& Partners Japan Limited

Ove Arup \& Partners Japan Limited

Grad. Student, Dept. of Architecture and Building, Graduate School of Engineering, Kanagawa Univ.

Assoc. Prof., Dept. of Architecture and Building Engineering, Kanagawa Univ., Dr. Eng. Prof., Dept. of Architecture and Building Engineering, Kanagawa Univ., Dr. Eng. 


\section{3. 斜行ルーバーの導入}

環境・エネルギー効率に配慮したファサードエンジニアリングは ヨーロッパを中心に近年発達が見られる ${ }^{7)}$, 8)。しかし、気候が大き く異なる日本に適用寸る上ではコンセプトの改良・変更が必要にな る ${ }^{9 \sim 11)}$ 。一方で、世界有数の地震国である日本では、既存建物の耐 震改修が喫緊の課題であり、外周部にブレースを配置する補強が一 般的に行われてきた。

ブレースは構造要素としての効率がよいことは言うまでもないが、 建物外観に構造要素が単純に付加されるだけでは、既存ストックの 性能向上及び魅力の再生として十分といえない。一方、環境を配慮 したファサードは、ルーバーを環境装置として利用する例（写真 1) が多く、高い環境性能を発揮し、かつ魅力ある景観を構成している。

ルーバーによる環境負荷低減の主目的は遮熱性能の向上である。 日射をルーバーにより反射し室内への侵入熱量を低減する。ファサ ード外部に設置されたルーバーは建物外部で熱侵入を防ぐため、近 年提案されてきたダブルスキンのように、内外の緩衝帯（キャビテ イ）で排熱するシステムよりも本来は遮熱効率に優れる (図 1) ${ }^{12)}$, 13)。 設計では、ルーバーは適切な遮熱効果が得られるように方位や太 陽高度から判断し、水平、縦型などの形状やピッチが調整される。 一般には、太陽高度の高い南面には水平ルーバー、東西面には縦型

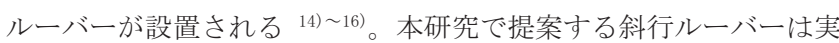
例をみないものであるが、太陽高度が中庸の高さである南東、南西 面に遮熱効果を発揮し（図 2）長時間に渡り遮熱効果を期待できる ものである。一方で眺望や室内照度の問題から、ルーバーの実物件 への適用が懸念されることが多い。ルーバータイプは遮熱に優れる システムであるが導入されないケースが多いのが実情である。室内 光環境については、ライトシェルフなど光を室内に導入するシステ ムが提案 (写真 2) されており、室内光環境を改善する機能があるも のの、これらは独立した環境装置であり、遮熱効果を狙って育面全 体にルーバーが設置されるケースはあまり検討されていない 17), 18)。

これらの観点から、斜行ルーバーを提案し、実物大実験及び解析 によって、室内からの眺望や室内光環境を検証する。
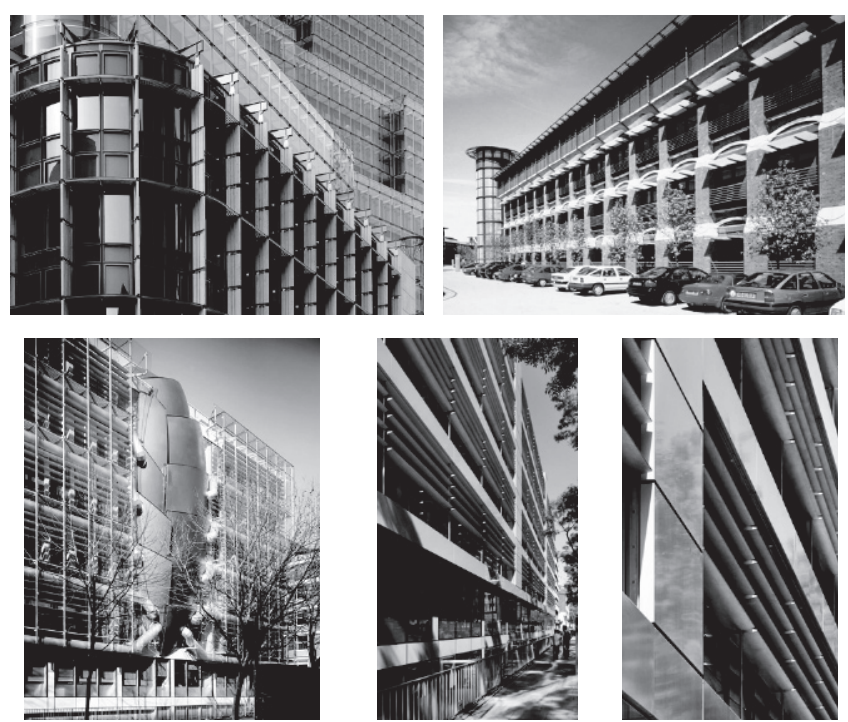

写真 1 環境を配慮したファサード
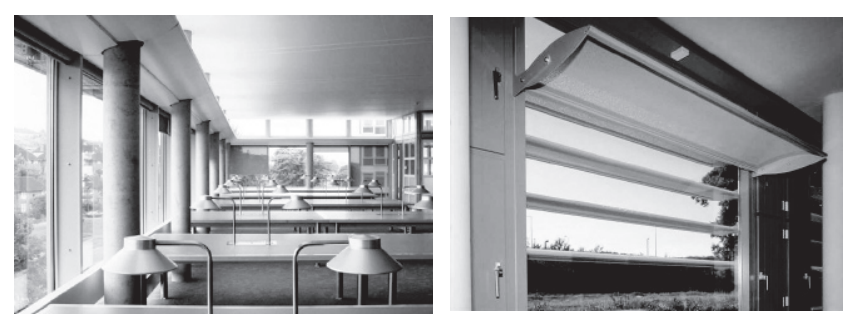

写真2＼cjkstart環境装置の導入例（ライトシェルフ）

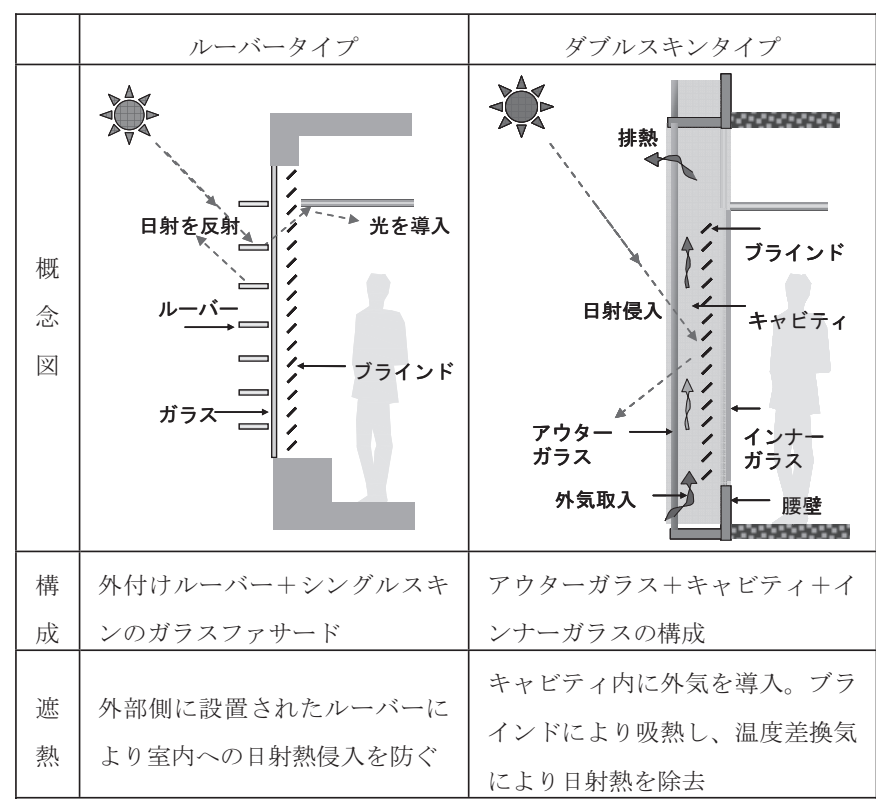

図1＼cjkstart環境配慮ファサードの遮熱メカニズム
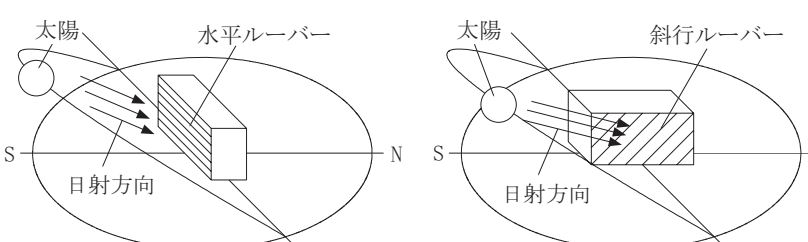

図2 ファサード方位と日射制御に有効なルーバータイプ

\section{4. 実物大実験}

\section{1 実験概要}

既存建物の改修を想定し神奈川大学 8 号館（北緯 35.29 度、東経 139.37 度）に適用する斜行ルーバーを検討する（図 3）。斜行ルー バーは、2 タイプ（Rタイプ、Cタイプ）の形状を設計する。ルーバ 一形状の決定にあたっては、ルーバーに BRB（断面寸法 $100 \mathrm{~mm} \times$ $100 \mathrm{~mm}$ ）を内蔵することが考慮されている。 R タイプは断面が長方形 で、ルーバーの妻面が外側を向いている。C タイプは断面が正方形 で、ルーバーの角部を外側に向けている。表 1 に $\mathrm{R}$ タイプ、C タイ プの建物 1 層分、柱 1 スパン分を取り出した実物大モックアップの 外観とルーバー断面を示す。BRB は全てのルーバーには入っておら ず、構造上必要なルーバーにのみ挿入する。本研究では、この 2 夕 イプの実物大モックアップを用いて照度測定を行う。 


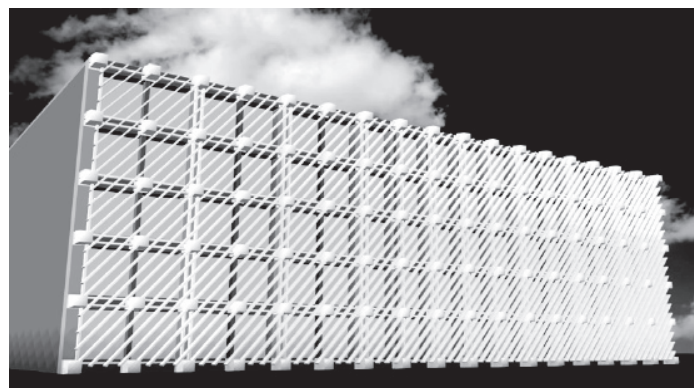

a） $\mathrm{R}$ タイプ外観

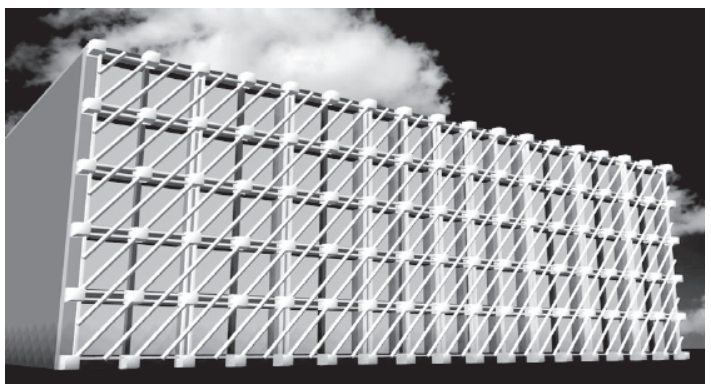

b) C タイプ外観

図 3 斜行ルーバーを設置したファサード

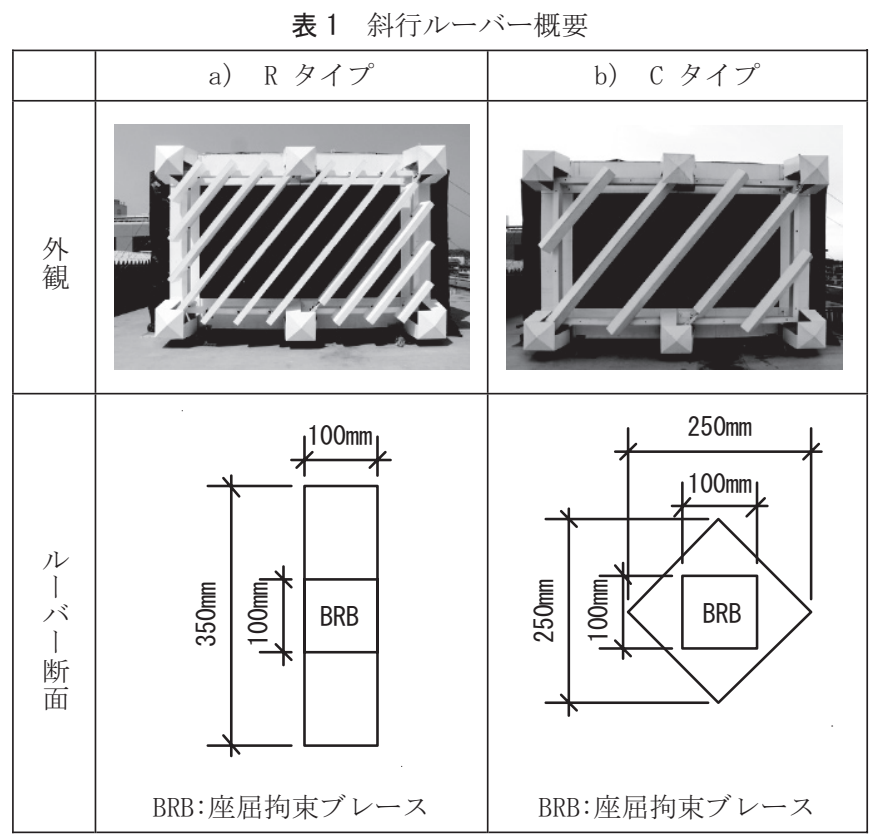

\section{2実物大モックアップ}

図 4 に実物大モックアップの構成を示す。既存建物を想定した躯 体枠に対し、1 次ファスナー、2 次ファスナー、パネル枠を用いてル 一バー及びブレースを接合する。ルーバーはパネル枠に、ブレース は 1 次ファスナーによって取り付け、接合部にはカバープレートを 取付ける。モックアップは白色塗料を塗布し、躯体枠内側はつや消 しの黒仕上とする。昼光率による評価を行うため、モックアップは、 天空に対する障害物が少ない神奈川大学 12 号館屋上に北向きで設 置する。設置環境及びモックアップ内観を写真 3 に示す。実物大モ ックアップは、建物内部のペリメータゾーンを想定し、幅 $4,400 \mathrm{~mm}$ ×奥行き $5,400 \mathrm{~mm} \times$ 高さ $3,450 \mathrm{~mm}$ とする。

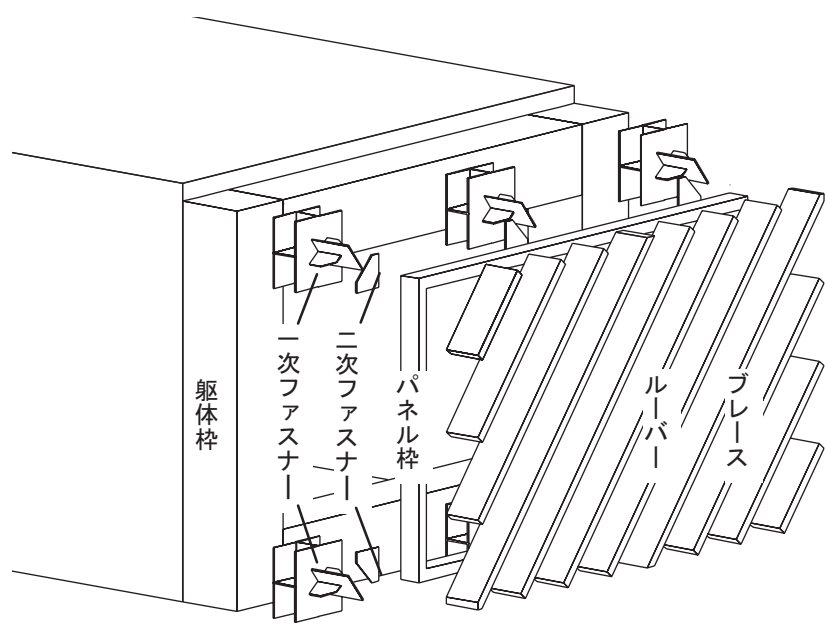

図 4 実物大モックアップの構成

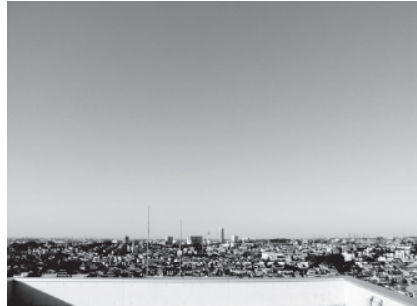

屋上周辺環境（北面）
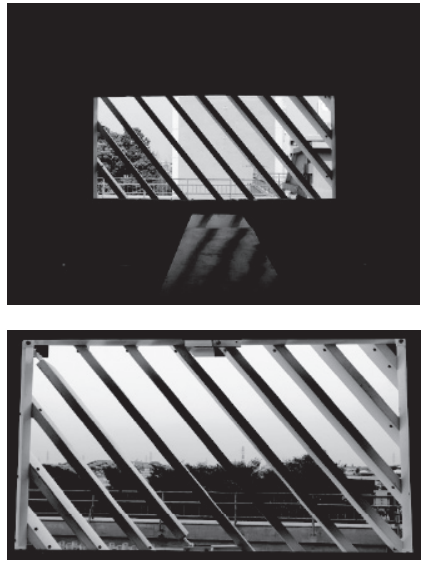

a) $\mathrm{R}$ タイプ (内観)

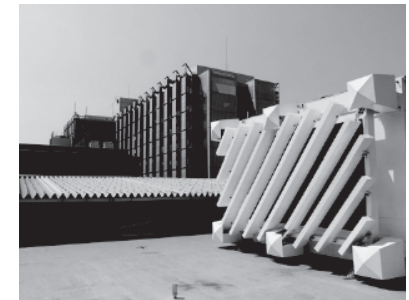

モックアップ周辺環境
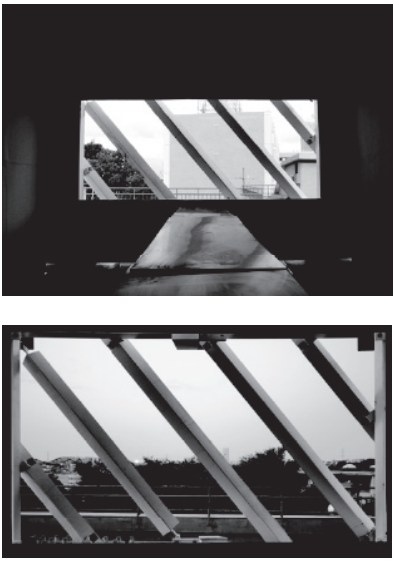

b) C タイプ (内観 $)$

\section{3実験条件}

表 2 に実験条件を示す。実験では室内照度及び全天空照度を計測 する ${ }^{19)}$ 21)。全天空照度は室内照度測定時と同時刻に、モックアッ プ設置位置に近接し、神奈川大学内で最も高い建物である神奈川大 学 23 号館屋上で測定する。写真 4 に全天空照度及び室内照度の測定 環境を示す。

写真 4 の台座中央に照度計を置き、直射日光を遮蔽して計測する。 直径 $100 \mathrm{~mm}$ の鉄製円盤に径 $10 \mathrm{~mm}$ 程度の鉄製棒を取り付けて黒テー プで覆ったものを直射日光の遮へい用具とし、受光部と円盤を $1 \mathrm{~m}$ 以上離して受光部に影を落とすように支えている。なお、影ができ ない曇天候の場合は使用していない。 
表 2 実験条件

\begin{tabular}{|c|c|}
\hline 項目 & 照度計測条件（外部環境） \\
\hline 天候 & 晴れ、または量り \\
\hline 計測日時 & 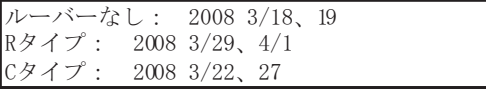 \\
\hline 計測場所 & $\begin{array}{l}\text { 北緯 } 35.29 \circ \text { 東経 } 139.37^{\circ} \\
\text { 全天空照度： 神奈川大学 } 23 \text { 号館屋上 } \\
\text { 至内照度： 神奈川大学 } 12 \text { 号館上 }\end{array}$ \\
\hline 周囲環境 & \begin{tabular}{|ll} 
全天空照度： 神奈川大学 23 号館屋上 (写真4) \\
室内照度： 神奈川大学 12 号館屋上 & (写真 4$)$ \\
\end{tabular} \\
\hline 計測機器 & \begin{tabular}{|l} 
全天空照度、室内照度 \\
デジタル照度計： TOPCON IM-2D \\
レンズ： IM-2D用倍率フィルタ (10M)
\end{tabular} \\
\hline 計測間隔 & $\begin{array}{l}\text { 全天空照度: 室内照度： } \\
\text { 9時から15時まで1时計測 }\end{array}$ \\
\hline
\end{tabular}

\begin{tabular}{|c|c|}
\hline 項目 & 実大モックアップ条件 (計測室) \\
\hline 形状/小法 & 幅4, 400mm x 奥行5, 500mm x 高さ3,450mm \\
\hline 開口方位 & 北面 \\
\hline \multirow{2}{*}{ 開口寸法 } & 幅 $3,900 \mathrm{~mm} \times$ 高さ $1,500 \mathrm{~mm}$ \\
\hline & 腰壁 $900 \mathrm{~mm}, \quad$ 垂壁 $1,000 \mathrm{~mm}$ \\
\hline 天井仕上 & 白色紙貼： 19.3 \\
\hline 壁仕上 & 白色紙貼： 19.3 \\
\hline 床仕上 & コンクリート： N5. 5 \\
\hline 開口仕上 & 開口：ガラスや建具などの嵌め込みなし \\
\hline
\end{tabular}

\begin{tabular}{|c|c|}
\hline 項目 & 実大モックアップ条件（ルーバー） \\
\hline \multirow{2}{*}{ 形状/寸法 } & (図5上図) \\
\hline & Cタイプ: \\
\hline \multirow{2}{*}{ 取り付け間隔 } & Rタイプ： @ $562.5 \mathrm{~mm}$ (スパン/8) \\
\hline & Cタイプ： @1125mm （スパン/4） \\
\hline \multirow{2}{*}{ 採光面の遮蔽率 } & Rタイプ： $22.68 \%$ \\
\hline & Cタイプ: $28.76 \%$ \\
\hline ルーバー仕上 & 白色塗装： N9.3 \\
\hline ルーバー取付枠 & 木製： 断面矩形 $100 \mathrm{~mm} \times 200 \mathrm{~mm}$ \\
\hline 取付枠仕上 & 白色塗装： N9.3 \\
\hline
\end{tabular}

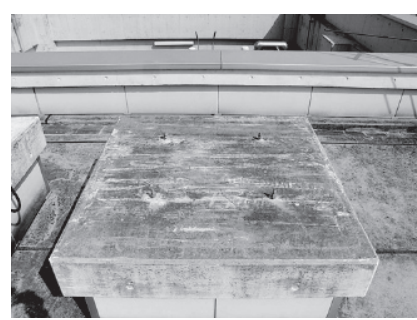

全天空照度測定

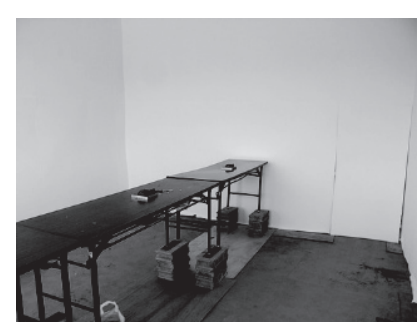

室内照度測定
写真 4 測定位置の周辺環境

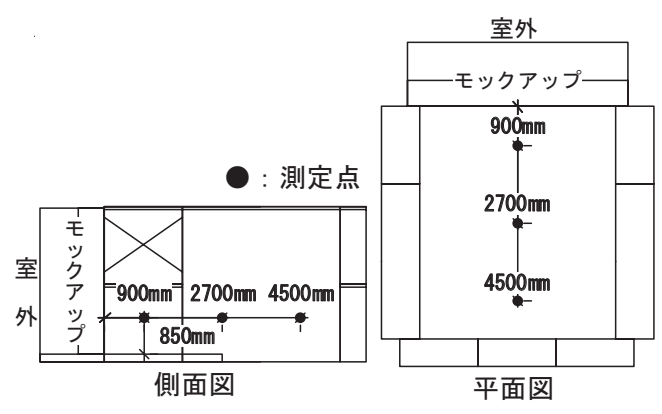

図 6 室内照度測定点

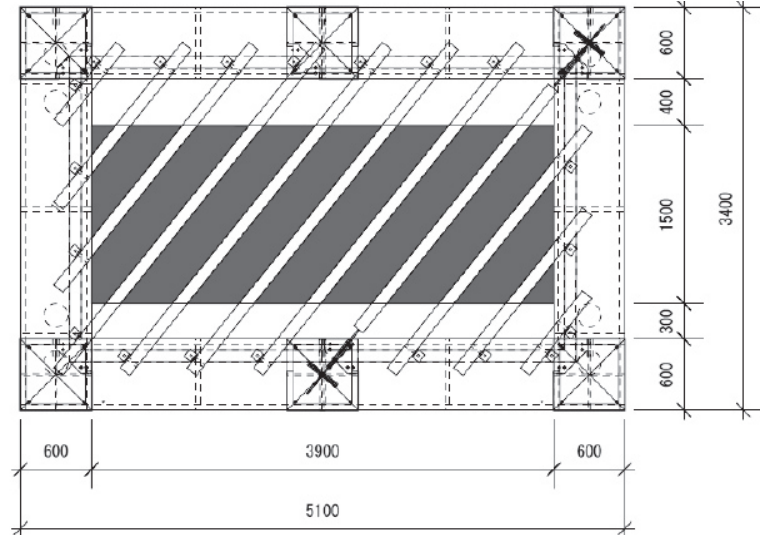

a） Rタイプの形状及び寸法

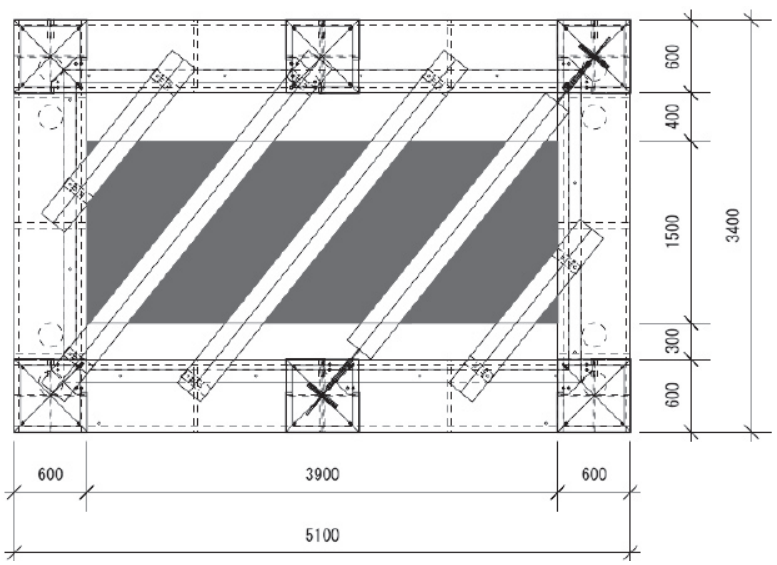

b） C タイプの形状及び寸法

図 5 モックアップ立面図

\section{4測定計画}

昼光率は、照度計によって照度を測定するものと、魚眼レンズを 用いた写真撮影によって立体角投射率を測定するものの 2 種類とす る。室内照度測定点を図 6 に示す。測定点における室内照度は、そ れぞれの条件で 2 日間、9 時から 15 時まで 1 時間ごとに測定する。 また、空面開口部に対する測定点からの立体角投射率についても、 それぞれの場合で 1 回ずつ測定する。測定值より毎時の昼光率を求 めるとともに、2 日間の平均值を算出する。魚眼レンズによる写真 撮影では、デジタルカメラ Nikon COOLPIX4500 に Nikon Fisheye converter FC-E8 を装着し、照度測定を行った地点で撮影する。魚眼 レンズのふちが測定高さ $1,025 \mathrm{~mm}$ となるように調整して撮影し、撮 影画像は $\mathrm{SPCONV}^{22)}$ を用いて立体角投射率を求める。

\section{5 実験結果}

表 3、表 4 に照度の測定結果および測定結果から算出した昼光率 を示す。また、測定点ごとに昼光率をプロットしたものを図 7 に、 実験結果のまとめを表 5 に示す。

昼光率は、天空光に対して室内で得られる明るさを示す割合であ る。一般には既存建物にルーバーを新設する場合、ルーバーの遮光 により室内が暗くなる印象があるが、測定結果をみると、必ずしも ルーバーによって室内の明るさが低下するとは言えない。ルーバー があっても室内が明るく、ペリメータ空間の光環境を改善する場合 もあり、空際から 4,500mm 離れた位置においてもルーバーなしとほ 
ぼ同様の明るさを示す結果となる。また、ルーバーが設置される場 合は、空際から $900 \mathrm{~mm}$ と $4,500 \mathrm{~mm}$ の昼光率の差がルーバーなしと 比べて小さく、ペリメータ空間の照度差が抑えられている。照度差 が抑えられることによって、人間に与える不快感が軽減される ${ }^{23) ~ 25) ~}$

魚眼レンズを用いた測定による直接昼光率は、空面開口部から直 接得られる天空光の割合を示す。これは周辺環境による光の反射や 拡散によって測定点の明るさが変化しても影響を受けない指標であ る。図 7 に示す直接昼光率と計測照度による昼光率の差は間接昼光 率である。間接昼光率は、内壁やルーバーの反射光による影響を示
すものである。間接昼光率は、空際から $2,700 \mathrm{~mm}$ 及び $4,500 \mathrm{~mm}$ にお いては、ルーバー無しに比べて、ルーバーを設置したほうが大きい。

これは、ルーバーによって、直接光の成分は低減するが、ルーバー が光を反射、拡散させて、間接光によって室奥まで明るくなるため といえる。C タイプ、R タイプともにその傾向にある。写真 3 の $\mathrm{R}$ タ イプ、C タイプの内観からも、ルーバーが天空光を受けて、光を反 射、拡散させていることが分かる。また、C タイプはルーバーの隙 間が広く、視線が外一抜けるため、ルーバーの設置による閉塞感も 軽減されている ${ }^{26)}$

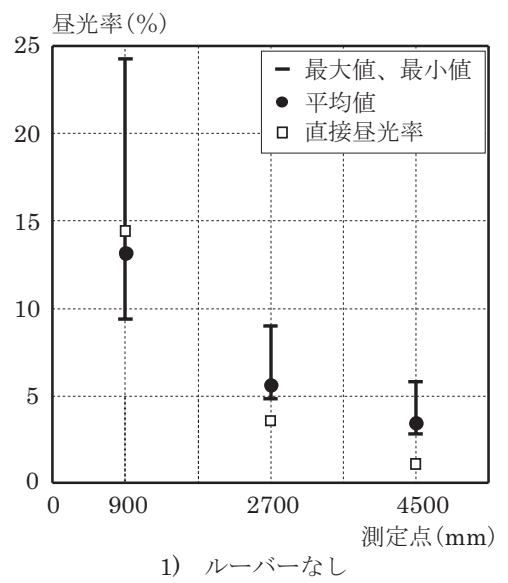

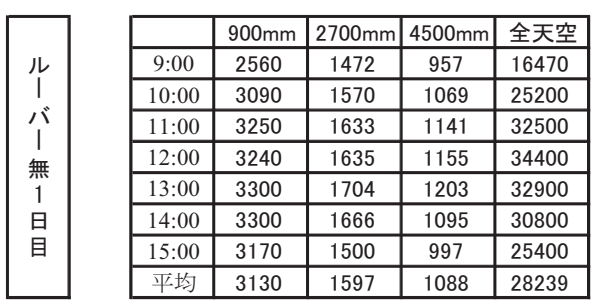

\begin{tabular}{|c|c|c|c|c|c|}
\hline \multirow[b]{2}{*}{ u } & $9: 00$ & 4460 & 1491 & 816 & 27400 \\
\hline & $10: 00$ & 4500 & 1811 & 1057 & 37100 \\
\hline \multirow{2}{*}{ バ } & 11:00 & 2190 & 811 & 484 & 9020 \\
\hline & $12: 00$ & 839 & 295 & 164 & 5280 \\
\hline \multirow{3}{*}{$\begin{array}{l}\text { 無 } \\
2\end{array}$} & 13:00 & 1620 & 602 & 338 & 10770 \\
\hline & 14:00 & 551 & 208 & 121 & 4140 \\
\hline & 15:00 & 992 & 339 & 181 & 5390 \\
\hline & 平均 & 2165 & 794 & 452 & 14157 \\
\hline
\end{tabular}

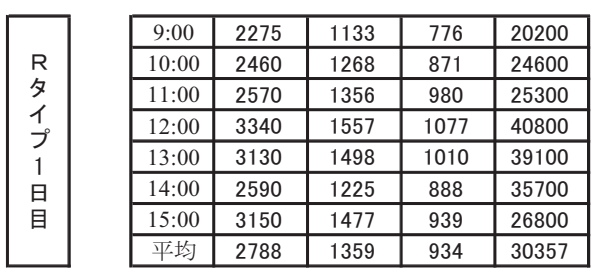

ルーバーなし

\begin{tabular}{|c|c|c|}
\hline $900 \mathrm{~mm}$ & $2700 \mathrm{~mm}$ & $4500 \mathrm{~mm}$ \\
\hline \multicolumn{3}{|c|}{2 間平均(昼光率) } \\
\hline 13.2 & 5.6 & 3.5 \\
\hline \multicolumn{3}{|c|}{ 2日間最大値 } \\
\hline 24.3 & 9.0 & 5.8 \\
\hline \multicolumn{3}{|c|}{ 2日間最小値 } \\
\hline 9.4 & 4.8 & 2.8 \\
\hline
\end{tabular}

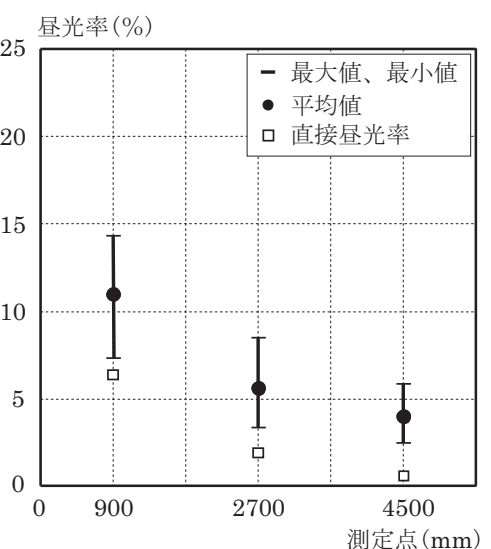

2) Rタイプ

図 7 測定結果（昼光率\%)

表 3 測定結果（照度 $1 x ，$ 昼光率 $\%$ )

\begin{tabular}{|c|c|c|}
\hline \multicolumn{3}{|c|}{ 昼光率 } \\
\hline 15.5 & 8.9 & 5.8 \\
\hline 12.3 & 6.2 & 4.2 \\
\hline 10.0 & 5.0 & 3.5 \\
\hline 9.4 & 4.8 & 3.4 \\
\hline 10.0 & 5.2 & 3.7 \\
\hline 10.7 & 5.4 & 3.6 \\
\hline 12.5 & 5.9 & 3.9 \\
\hline 11.1 & 5.7 & 3.9 \\
\hline
\end{tabular}

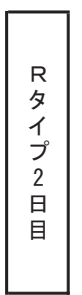

\begin{tabular}{|c|c|c|c|c|}
\hline & $900 \mathrm{~mm}$ & $2700 \mathrm{~mm}$ & $4500 \mathrm{~mm}$ & 全天空 \\
\hline 9:00 & 1603 & 884 & 653 & 11210 \\
\hline $10: 00$ & 1658 & 928 & 682 & 12770 \\
\hline $11: 00$ & 1632 & 928 & 704 & 11970 \\
\hline $12: 00$ & 1639 & 914 & 706 & 12900 \\
\hline $13: 00$ & 1730 & 1042 & 695 & 12300 \\
\hline $14: 00$ & 2440 & 939 & 756 & 20200 \\
\hline $15: 00$ & 2150 & 1059 & 777 & 18900 \\
\hline 平均 & 1836 & 956 & 710 & 14321 \\
\hline
\end{tabular}

\begin{tabular}{|l|l|l|}
\hline \multicolumn{3}{|c|}{ 昼光率 } \\
\hline 14.3 & 7.9 & 5.8 \\
\hline 13.0 & 7.3 & 5.3 \\
\hline 13.6 & 7.8 & 5.9 \\
\hline 12.7 & 7.1 & 5.5 \\
\hline 14.1 & 8.5 & 5.7 \\
\hline 12.1 & 4.6 & 3.7 \\
\hline 11.4 & 5.6 & 4.1 \\
\hline 12.8 & 6.7 & 5.0 \\
\hline
\end{tabular}

\begin{tabular}{|l|l|l|}
\hline 16.3 & 5.4 & 3.0 \\
\hline 12.1 & 4.9 & 2.8 \\
\hline 24.3 & 9.0 & 5.4 \\
\hline 15.9 & 5.6 & 3.1 \\
\hline 15.0 & 5.6 & 3.1 \\
\hline 13.3 & 5.0 & 2.9 \\
\hline 18.4 & 6.3 & 3.4 \\
\hline 15.3 & 5.6 & 3.2 \\
\hline
\end{tabular}
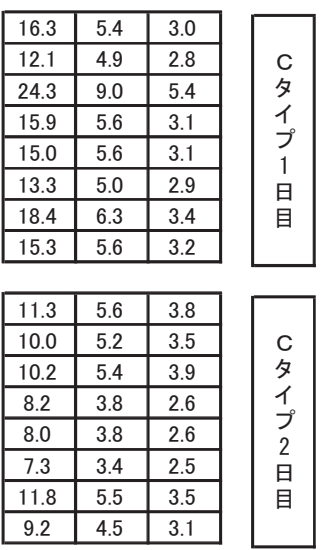

\begin{tabular}{|c|c|c|c|c|}
\hline 9:00 & 1986 & 1093 & 772 & 15400 \\
\hline $10: 00$ & 1975 & 1118 & 785 & 17700 \\
\hline $11: 00$ & 1984 & 1149 & 833 & 18600 \\
\hline $12: 00$ & 2030 & 1147 & 832 & 19700 \\
\hline $13: 00$ & 2180 & 1227 & 879 & 20700 \\
\hline $14: 00$ & 2210 & 1211 & 860 & 19200 \\
\hline $15: 00$ & 2340 & 1216 & 831 & 17530 \\
\hline 平均 & 2101 & 1166 & 827 & 18404 \\
\hline
\end{tabular}

\begin{tabular}{|l|l|l|}
\hline 12.9 & 7.1 & 5.0 \\
\hline 11.2 & 6.3 & 4.4 \\
\hline 10.7 & 6.2 & 4.5 \\
\hline 10.3 & 5.8 & 4.2 \\
\hline 10.5 & 5.9 & 4.2 \\
\hline 11.5 & 6.3 & 4.5 \\
\hline 13.3 & 6.9 & 4.7 \\
\hline 11.4 & 6.3 & 4.5 \\
\hline
\end{tabular}

\begin{tabular}{|c|c|c|c|c|}
\hline 9:00 & 3610 & 1354 & 837 & 35800 \\
\hline $10: 00$ & 4450 & 1688 & 1015 & 48400 \\
\hline $11: 00$ & 3950 & 1426 & 886 & 46800 \\
\hline $12: 00$ & 1981 & 1146 & 847 & 16520 \\
\hline $13: 00$ & 2220 & 1231 & 902 & 17140 \\
\hline $14: 00$ & 3490 & 1561 & 998 & 26000 \\
\hline $15: 00$ & 2890 & 1255 & 780 & 13280 \\
\hline 平均 & 3227 & 1380 & 895 & 29134 \\
\hline
\end{tabular}

\begin{tabular}{|c|c|c|}
\hline 10.1 & 3.8 & 2.3 \\
\hline 9.2 & 3.5 & 2.1 \\
\hline 8.4 & 3.0 & 1.9 \\
\hline 12.0 & 6.9 & 5.1 \\
\hline 13.0 & 7.2 & 5.3 \\
\hline 13.4 & 6.0 & 3.8 \\
\hline 21.8 & 9.5 & 5.9 \\
\hline 11.1 & 4.7 & 3.1 \\
\hline
\end{tabular}

表 4 昼光率の平均值及び最大, 最小值（\%)

Rタイプ

\begin{tabular}{|c|c|c|}
\hline $900 \mathrm{~mm}$ & $2700 \mathrm{~mm}$ & $4500 \mathrm{~mm}$ \\
\hline \multicolumn{2}{|c|}{ 2日間平均(昼光率) } \\
\hline 11.0 & 5.6 & 4.0 \\
\hline \multicolumn{3}{|c|}{2 明間大最大値 } \\
\hline 14.3 & 8.5 & 5.9 \\
\hline \multicolumn{3}{|c|}{2 目間最小値 } \\
\hline 7.3 & 3.4 & 2.5 \\
\hline
\end{tabular}

Cタイプ

\begin{tabular}{|c|c|c|}
\hline $900 \mathrm{~mm}$ & $2700 \mathrm{~mm}$ & $4500 \mathrm{~mm}$ \\
\hline \multicolumn{2}{|c|}{ 2日間平均(昼光率) } \\
\hline 11.2 & 5.5 & 3.8 \\
\hline \multicolumn{3}{|c|}{2 明間最大値 } \\
\hline 21.8 & 9.5 & 5.9 \\
\hline \multicolumn{3}{|c|}{ 2日間最小値 } \\
\hline 8.4 & 3.0 & 1.9 \\
\hline
\end{tabular}


表5＼cjkstart実験結果まとめ

\begin{tabular}{|c|c|c|}
\hline 測定 & 昼光率 (平均値) の特徴 & 昼光率（平均値）と直接昼光率の差 \\
\hline mm & $\begin{array}{l}\text { ルーバーなしが最も高くRタイ } \\
\text { プが最も低い。 }\end{array}$ & $\begin{array}{l}\text { ルーバーなし、Cタイプでは、昼光率（平均 } \\
\text { 値）が直接昼光率と同じであるが、ルーバー } \\
\text { が多いRタイプでは上回る。 }\end{array}$ \\
\hline $2,700 \mathrm{~mm}$ & どの㘿 & $\begin{array}{l}\text { どの場合も昼光率（平均値）が直接昼光率を } \\
\text { 上回る。 }\end{array}$ \\
\hline & ーバーーなしの場合よりも & $\begin{array}{l}\text { どの場合も昼光率 (平均値) が直接昼光率を } \\
\text { 上回り、ルーバーありの場合は差が大きい。 }\end{array}$ \\
\hline
\end{tabular}
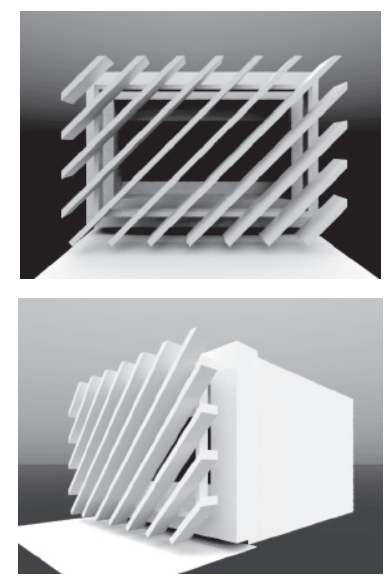

a) $\mathrm{R}$ タイプ
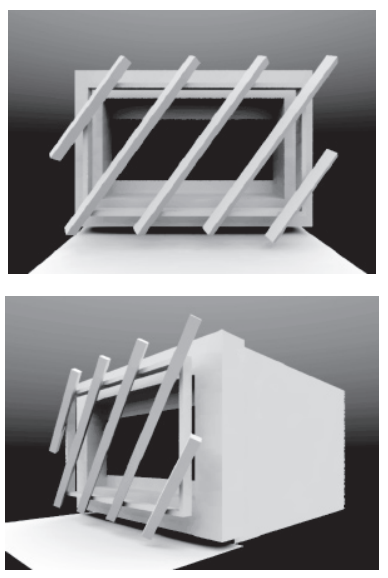

b) Cタイプ

図 8 室内照度解析モデル

\section{5. 光環境解析}

\section{1 解析条件}

光環境解析には解析ソフトRadiance を使用寸る。Radiance はカ ルフォルニア州ローワンス・バークリー研究所で開発された照度可 視化システムである。表 6 に解析条件を示寸。図 8 に解析モデルを 示す。Radiance では、実測点からランダムに光線を飛ばし、光源に 到達した光線をもとに、モンテカルロ法にて解析を行う。より多く の光線数を設定すれば、より正確な結果が得られる。本研究では、 室形状が矩形であるため解析時間も少ないと考え、光線数は設定最 高値の 4096 本とする。また、光線が光源に到達するまでの室内にお ける反射についても反射回数を設定最高值 8 回とし解析を実施する。

表 6 解析条件

\begin{tabular}{|c|c|}
\hline 天空設定 & CIE標淮曇天空 全天空照度 $15,0001 x$ \\
\hline 周囲環境 & 周囲に障害物なし \\
\hline 光線数 & 4096本 (最大值) \\
\hline 反射回数 & 8回（最大値） \\
\hline 室内形状 / 寸法 & 幅 $4,700 \mathrm{~mm} x$ 奥行 $5,500 \mathrm{~mm} x$ 高さ $3,475 \mathrm{~mm}$ \\
\hline 開口方位/小法 & 北面 $/$ 幅 $3,900 \mathrm{~mm} \times$ 高さ $2,200 \mathrm{~mm}$ \\
\hline $\begin{array}{c}\text { 天井／壁及び } \\
\text { ルーバー／取付枠仕上 }\end{array}$ & \begin{tabular}{|lll} 
オフホワイトペイント & & \\
$\mathrm{R} 0.691$ G 0.696 B $0.615 \quad$ (反射率 $68.8 \%$ )
\end{tabular} \\
\hline 床仕上 & \begin{tabular}{|llllll} 
コンクリート & & & \\
$\mathrm{R}$ & 0.244 G & 0.194 & B & 0.145 (反射率 $20.3 \%$ ) \\
\end{tabular} \\
\hline 開口仕上 & ガラスや建具などの嵌め込みなし \\
\hline
\end{tabular}
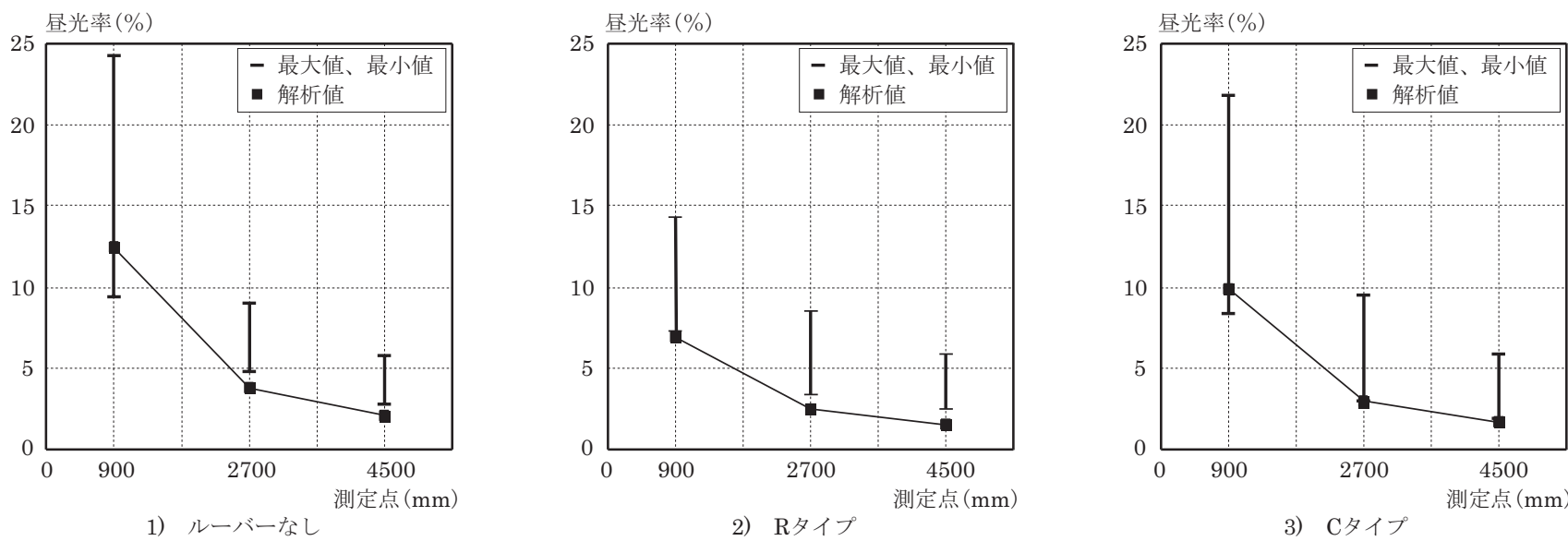

図 9 測定值と解析值の比較（昼光率％）
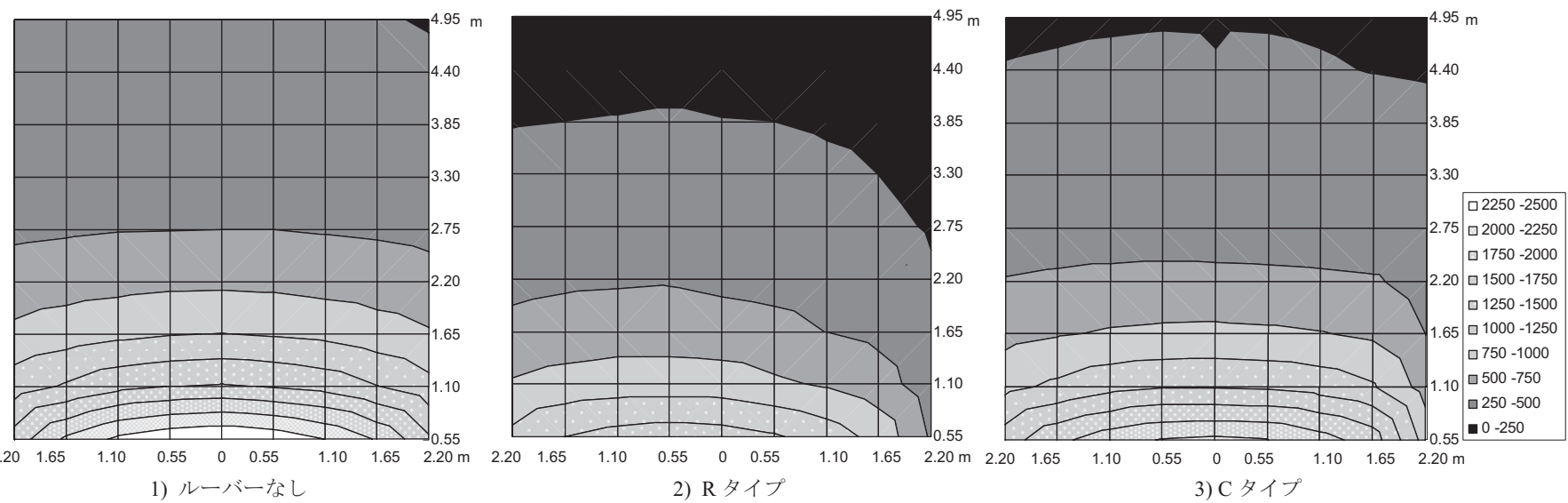

図 10 室内照度分布（解析值 $1 \mathrm{x}$ ）（縦軸は空面からの距離、横軸は空面中心軸からの距離を示寸） 


\section{2 測定値との比較}

図 9 に測定值と解析值の昼光率の比較を示寸。解析值は、測定值 より低い值を示すものの、よい相関を示すことが分かる。斜行ルー バーの実例は類をみないが、設計段階においても事前に解析検討を 行うことによって、信頼性のある評価ができるといえる。

また、斜行ルーバーを配置したファサードの室内照度分布を図 10 に示す。斜行ルーバーを配置する場合、ルーバーが無い場合よりも、 照度分布に若干偏りがみられるが、C タイプでは照度分布にほとん ど偏りがみられず、ルーバーの形状や取り付けピッチを調整するこ とにより、照度の偏りは十分に改善される。

\section{6. 結論}

斜行ルーバーを設置したファサードの室内光環境を把握するため、 実物大モックアップによる照度の測定及び解析を行った。その結果、 以下の知見を得た。

(1) 斜行ルーバーの設置よって、空際と室内奥の室内照度差が低減 され、不快感を軽減し、ペリメータ空間の光環境を改善させる効果 が得られる。

(2) 斜行ルーバーの設置によって、ルーバーにより光を反射、拡散 させて室内奥まで光が到達する。そのため、室内奥であってもルー バーが無い場合と同様の明るさが得られる。

(3) 斜行ルーバーの設置によって、室内照度分布に偏りがみられる 場合があるが、ルーバーの形状及びピッチを調整することにより、 照度分布の偏りは十分に改善される。

(4) 照度測定值と解析值には相関があり、斜行ルーバーの室内光環 境について、信頼性のある設計ツールとして展開できる。

\section{謝辞}

本研究は、国土交通省、平成 20 年度住宅・建築関連先導技術開発助 成事業費補助金、“補助事業の名称 : 意匠・構造・環境の性能向上 を同時に図る「統合ファサードシステム」による既存ストックの再 生技術の開発”により行われたものです。本研究のモックアップの 設計、製作にあたりご指導頂きました、前田一級建築事務所、前田 親範氏に感謝の意を表します。また、光環境シミュレーションにあ たりアラップジャパン平井礼子氏、モックアップの製作、実験の遂 行にあたり神奈川大学学部生(当時)只木浩之氏の協力を得ました。 ここにあわせて感謝の意を表します。

\section{参考文献}

1)竹内㛩、小谷野一尚、岩田衛 : ファサードエンジニアリングの統合に関する 研究一既存ファサードの性能調查・分析一, 日本建築学会環境系論文集, No.592, pp.97-104, 2005.6

2)竹内徹、小谷野一尚、安田幸一、湯浅和博、岩田衛 : ファサードエンジニア リングの統合に関する研究一統合ファサードの提案および性能評価一, 日 本建築学会環境系論文集, No.601, pp.81-88, 2006.3

3)竹内徹、安田幸一、湯浅和博、岡山俊介、宮㠃健太郎、岩田衛 : 統合ファ严 一ドによる既存不適格建物の耐震改修, 日本建築学会技術報告集, No.24, pp.161-166, 2006.12

4)竹内徾、岩田衛、安田幸一: 構造設計からの取り組み, コンクリート工学 500 号記念特集号*環境とコンクリート vol45, No.5, 2007.5

5)金木洋平、竹内徾、宮㠃健太郎、岩田衛 : ファサードエンジニアリングの統 合に関する研究 一統合ファサードの構造性能一, 日本建築学会技術報告 集, No.27, pp.137-142, 2008.6

6)金木洋平、彦根茂、山下哲郎、岩田衛: 斜行配置座屈拘束ブレースによる耐 震補強, 日本建築学会構造系論文集, No.634, pp.2215-2222, 2008.12

7)Alison G. Kwok, AIA 、Walter T. Grondzik, PE : The GREENSTUDIO HANDBOOK, Architectural Press, 2007
8)Thomas Herzog、 Roland Krippner、Werner Lang : Façade Construction Manual, Birkhauser-Publishers for Architecture, 2004

9) 日本建築学会偏 : 地球環境建築の寸寸め, 彰国社, 2002.8

10)建築画報特別号 : Façade Engineering,Vol39,2003.12

11)日本建築学会 : ガラスの建築学, 学芸出版社, 2004

12)Michael J. Crosble : CURTAIN WALLS、Birkhauser-Publishers for Architecture, 2005

13)Oesterle、Lieb、Lutz、Heusler : Double-Skin Facades, Prestel, 2001

14) 日本建築学会・採光設計, 技報堂, 1963

15)日本建築学会設計計画パンフレット 16 採光設計, 彰国社, 1963

16)浦野良美, 中村洋 : 建築環境工学, 森北出版株式会社, 1996.6

17)日本建築学会設計計画パンフレット 23 照明設計, 彰国社, 1975

18)日本建築学会設計計画パンフレット 30 昼光照明の計画, 彰国社, 1985

19)日本建築学会設計計画パンフレット 24 日照の測定と検討, 彰国社, 1977

20)昼光照明の計算法, 日本建築学会, 1993

21)小木曾定彰、小池利幸 : 昼光率の実測に影響を与える各種の要因について, 日本建築学会大会学術講演梗概集, pp.69-67, 1978.9

22)永田明寛. BUILDING SIMULATION RESOURCES Library, Application and Database.SPCONV.2005-01-05.http://news-sv.aij.or.jp/kankyo/s12/Resource/ap/S PCONV/SPCONV.htm. (参照 2007-12-12).

23)照明学会・技術基準 オフィス照明基準 JIEC-001, 1992 24)照明学会・技術基準 住宅照明基準 JIEC-005, 1994

25)日本工業規格 照度基準 JIS Z 9110-1979

26)照明学会・ライティングハンドブック、オーム社, 1987. 11

(2009年 2 月 6 日原稿受理, 2009 年 7 月 7 日採用決定) 